\title{
ANALISIS PENYUSUNAN STRATEGI DAN PROGRAM PEMBINAAN USAHA MIKRO KECIL DKI JAKARTA AKIBAT PANDEMIC COVID 19 DENGAN PENDEKATAN USG DAN SWOT
}

\author{
Yurianto \\ BPSDM DKI Jakarta \\ Email : yuribpsdm@gmail.com
}

\begin{abstract}
ABSTRAK
Kedatangan wabah virus korona telah merubah tatanan kehidupan secara signifikan. Suka atau tidak, setiap orang, bahkan pelaku usaha harus beradaptasi. Beragam upaya dilakukan, tidak terkecuali penetapan strategi. Bagi pelaku usaha kecil, hal ini adalah kejadian luar biasa. Sebab, ruang gerak menjadi sangat terbatas. Oleh karenanya, menelaah keadaan (internal dan eksternal) perlu dilakukan secara seksama, sehingga menghasilkan formulasi usaha yang tepat di tengah pandemi. Penelitian ini bertujuan untuk menelaah strategi bisnis yang relevan digunakan oleh UMK di Provinsi DKI Jakarta akibat pandemi Covid 19. Untuk menindaklanjuti kegiatan ini, maka diperlukan suatu cara-cara ilmiah, di antaranya melakukan riset mendalam dengan pendekatan kualitatif. Selanjutnya, data dianalisis menggunakan metode analisis deskriptif (USG, SWOT, EFAS, dan IFAS). Berdasarkan hasil analisis, maka strategi yang perlu diterapkan dalam pembinaan usaha mikro kecil pada masa Pandemic Covid 19 adalah menggunakan kekuatan untuk memanfaatkan peluang jangka panjang dengan cara strategi diversifikasi (produk/jasa).
\end{abstract}

Kata Kunci : USG, SWOT, EFAS, dan IFAS

\begin{abstract}
The arrival of the corona virus outbreak has significantly changed the order of life. Like it or not, everyone, even business people, must adapt. Various efforts were made, including in determining strategies. For small business operators, this is an extraordinary event. This is because the space for movement is very limited. Therefore, analyzing the situation (internal and external) needs to be done carefully, so as to produce the right business formulation in the midst of a pandemic. This study aims to examine the relevant business strategies used by MSEs in DKI Jakarta Province due to the Covid 19 pandemic. To follow up on this activity, scientific methods are needed, including conducting in-depth research with a qualitative approach. Furthermore, the data were analyzed using descriptive analysis methods (USG, SWOT, EFAS, and IFAS). Based on the results of the analysis, the strategy that needs to be applied in fostering micro and small businesses during the Covid 19 Pandemic is to use strength to take advantage of long-term opportunities by means of a diversification strategy (products / services).
\end{abstract}

Keywords : USG, SWOT, EFAS, dan IFAS

\section{PENDAHULUAN}

Krisis Kesehatan yang terjadi akibat Pandemic Covid 19 berdampak luas dan multi dimensi. Kondisi ini berdampak bukan hanya aspek Kesehatan saja tetapi lebih dari itu. Dampak lain mencakup pada aspek ekonomi aspek keuangan aspek sosial aspek politik dan aspek budaya. Beberapa ahli mengatakan bahwa dampak krisis ini lebih serius dibanding dengan krisis ekonomi pada tahun 1998. Mengingat krisis yang demikian maka cara penaangannyanya pun sebaiknya harus di lakukan secara multidimensional bukan dilakukan secara sectoral dan parsial. Penangannya harus 
melalui cara yang biasa saja. Dalam hal ini diperlukan usaha yang lebih sistematis, partisipatif, dan komprehensif.

Pada aspek ekonomi, kondisi kontraksinya akibat Pandemic Covid 19 dapat digambarkan pada beberapa data. Data Kementerian Tenaga Kerja bahwa per 27 Mei 2020 mencatat dampak Covid-19 menyebabkan jumlah pekerja sektor formal yang telah dirumahkan sebanyak 1.058 .284 orang dan pekerja sektor formal yang di PHK sebanyak 380.221 orang. Sedang sektor informal yang terdampak COVID-19 sebanyak 318.959 orang. Total pekerja sektor formal dan informal yang terdampak COVID-19 sebanyak 1.757.464 orang (Kemenaker, 2020).

Menurut Setiawan dalam Sugiri, bahwa sampai dengan 17 April 2020, sebanyak 37.000 pelaku UMKM terdampak pandemi COVID-19 [1]. melaporkan diri kepada Kementerian Koperasi dan UKM. Menurut rilis data tersebut, kesulitan yang dialami oleh UMKM selama pandemi itu terbagi dalam empat masalah. Pertama, terdapat penurunan penjualan karena berkurangnya aktifitas masyarakat di luar luar sebagai konsumen. Kedua, kesulitan permodalan karena perputaran modal yang sulit sehubungan tingkat penjulan yang menurun. Ketiga, adanya hambatan distribusi produk karena adanya pembatasan pergerakan penyaluran produk di wilayah-wilayah tertentu. Keempat, adanya kesulitan bahan baku karena sebagai UMKM menggantungkan ketersediaan bahan baku dari sektor industri lain. Tabel 2 memperlihatkan bahwa dari keempat persoalan tersebut, dampak penurunan penjualan menjadi persoalan terbesar yang dirasakan oleh pelaku UMKM. Dampak pandemi terhadap UKM diyakini dapat lebih besar, karena tingginya tingkat kerentanan dan minimnya ketahanan akibat keterbatasan sumber daya manusia, supplier, dan opsi dalam merombak model bisnis [2,3].

Akibat Covid 19 juga dikemukaan oleh Baker and Judge bahwa Usaha mikro dan kecil merupakan usaha yang serius terdampak oleh adanya Covid 19 [4]. Kelompok ini mengahadapi cash flow yang semakin tidak likuid dan kemungkinan cash flow nya tidak tahan lama. Kondisi ini menjadikan Pemerintah harus segera menysuusn kebijakan yang pro usaha mikro kecil agar kelompok usaha ini dapat melakukan usahanya secara normal.

Pada tataran aktivitas usaha mikro kecil dampaknya juga cukup signifikan. Jika pada saat krisis ekonomi 1998, usaha mikro, kecil masih bisa bertahan, bahkan mampu menjadi penyelamat perekonomian Indonesia dengan menyediakan lapangan kerja bagi pekerja yang ter-PHK akibat krisis ekonomi tersebut [5].

Dampak ekonomi Pandemic Covid 19 dapat ke aspek produksi, distbribusi maupun konsumsi para pelaku usaha usaha mikro dan kecil. Hal ini sejalan dengan yang dikemukakan oleh Kementerian Koperasi dan Usaha Kecil Menengah bahwa pandemi Covid-19 berdampak signifikan bagi pelaku UMKM di Indonesia, baik dari sisi supply maupun demand 9Okezone.com, 30 AGustus 2020).

Dalam hal produksi yang merupakan representasi dari aspek penawaran diperkirakan akan menurun kinerjanya. Sejarah membuktikan bahwa peran produksi yang dilakukan oleh sector bisnis memegang peran penting dalam penyelenggaraan kesejahteraan sosial seluruh warga masyarakat karena dunia bisnis merupakan kelompok produsen yang mampu melihat kebutuhan barang dan jasa yang dibutuhakn masyarakat pada waktu dan tempt tertentu. 
Namun wabah pandemic Covid 19 sangat mempengaruhi aktivitas produksi usaha mikro kecil Jakarta. Para pelaku usaha sangat tergantung dari harga bahan baku yang langka di pasaran karena berbagai sebab. Ditambah lagi karena kebijakan PSBB menjadikan para pelaku usaha terpengaurah terutama dalam hal distribusi bahan baku. Akibat kelangkaan ini beberapa harga bahan baku merangkak naik. Dengan meningkatnya harga bahan baku maka harga porduk jauh akan merangkak naik. Hal ini membawa kesulitan bagi aktivitas produksi usaha mikro dan kecil. Data yang disampaikan LIPI yang merupakan hasil survey bahwa pandemic Covid 19 menyebabkan 39,4 persen pengusaha menghentikan produksi dan 57,1 persen usaha tetap berjalan dengan tingkat produksi yang menurun.

Usaha yang banyak terhenti kegiatan usaha adalah jenis usaha yang banyak melakukan interaksi dengan orang lain, seperti perdagangan ritel sebesar $45,2 \%$, jasa kemasyarakatan sebesar $49,8 \%$. Begitu juga jenis usaha yang membutuhkan modal dan tenaga kerja yang cukup banyak, seperti sektor konstruksi dan bangunan sebanyak $44,2 \%$, dan jasa perusahaan sebesar $50,7 \%$. Sementara usaha yang mengurangi produksi hampir terjadi pada semua sektor ekonomi, tetapi menonjol pada sektor industri pengolahan, listrik, gas dan air minum, pertambangan dan penggalian, dan usaha sektor pertanian.

Pada aspek distribusi, kebijakan pemereinth dengan pemberlakukan PSBB juga telah banyak memengaruhi proses distribusi produk usaha mikro kecil. Paling tidak kebijakan ini meningkatkan ongkos distribusi. Selain itu kebijakan pemberlakuan lalu lintas ganjil genap juga secara langsung memengaruhi proses distirbusi produk usaha mikro kecil. Arus distribusi komoditas pangan ini terganggu sehingga harga pangan cenderung meningkat terutama pada daerah yang terkena dampak besar. Sebagai contoh harga bawang merah tinggi, walaupun stok tersedia di sentra produksinya. Hal ini karena arus trasnportasi dibatasi sehingga terjadi kenaikan harga di daerah yang bukan sentra produksi.

Pola konsumsi yang merupakan represntasi dari fungsi permintaan usaha mikro kecil juga terpengaruh oleh wabah Pandemic Covid 19. Konsumsen cenderung tinggal di rumah. Konsumen memesan melalui on line /daring ke para produsen. Dari sisi produk permintaan produk usaha mikro kecil yang tidak berkaitan dengan produk kesehatan dan bahan pangan pokok akan mennurun. Konsumen akan memprioaritaskan membeli produk yang dapat mencegah atau mengobati virus corona, seperti produk masker, hand sanitizer, dan empon empon. Produk lain yang tetap laku adalah produk tertentu seperti bahan pangan pokok. Kondisi ini memengaruhi kelangsungan usaha mikro kecil secara signifikan. Secara keselaruhan hal ini memengaruhi tingkat penjualan para usaha mirko kecil yang belum menggunakan fasilitas pemasaran on line/daring. Kondisi ini pada gilirannya hal ini sangat memengaruhi pendapatan usaha mikro kecil.

Menurut Murdani, et al., bahwa isu penting yang dihadapi Usaha Mikro Kecil Menengah sangat beragam namun yang utama adalah kualitas sumber daya manusia, kurang mantapnya kelembagaan, dan lemahnya penguasaan teknik pemasaran [6]. Ini artinya bahwa dalam pengembangan usaha mikro kecil permasalahan tersebut harus dipecahkan terlebih dahulu.

Mencermati kondisi tersebut usaha mikro kecil terkena dampak serius dan mendalam. Ini artinya jika kelompok usaha ini tidak dibantu dan dibina maka sudah 
dapat dipastikan bahwa pelaku usaha mikro dan kecil akan terus menurun kinerjanya. Dengan mencermati hal tersebut salah satu permasalahan yang krusial adalah bagaimana membangkitkan usaha Mikro dan Kecil dalam menghadapi Pandemic Covid 19 agar para pelaku usaha mikro kecil dapat beraktivitas dengan baik dan memperolah keuntungan yanga wajar. Untuk membahas hal ini maka diperlukan diskusi yang mendalam tentang pola pembinaan yang berkaitan dengan isu pembinaan usaha mikro kecil guna meningkatkan keberdayaan pelaku usaha mikro kecil di Jakarta pada era new normal. Hasil dari kajian ini diharapkan dapat menjadi masukan dan saran bagi pemberdayaan usaha mikro dan kecil di Jakarta.

\section{LANDASAN TEORI}

Usaha mikro kecil berperan penting dalam menjadikan perekonomian Jakarta resilience dan sustainable. Peran ini ditunjukkan oleh aktivitas dan perilaku usahanya yaitu sebagai mesin pertumbuhan ekonomi dan penyerapan tenaga kerja serta sebagai distributor hasil-hasil pembangunan. Menurut Bank Indonesia dan LPPI bahwa UMKM juga telah terbukti tidak terpengaruh terhadap krisis. Ketika krisis menerpa pada periode tahun 1997 - 1998, hanya UMKM yang mampu tetap berdiri kokoh [7].

Data Badan Pusat Statistik dalam BI dan LPPI memperlihatkan, pasca krisis ekonomi tahun 1997-1998 jumlah UMKM tidak berkurang, justru meningkat terus, bahkan mampu menyerap 85 juta hingga 107 juta tenaga kerja sampai tahun 2012. Pada tahun itu, jumlah pengusaha di Indonesia sebanyak 56.539.560 unit. Dari jumlah tersebut, Usaha Mikro Kecil dan Menengah (UMKM) sebanyak 56.534.592 unit atau 99.99\%. Sisanya, sekitar $0,01 \%$ atau 4.968 unit adalah usaha besar. Data tersebut membuktikan, UMKM merupakan pasar yang sangat potensial bagi industri jasa keuangan, terutama bank untuk menyalurkan pembiayaan. Karena sekitar $60-70 \%$ pelaku UMKM belum memiliki akses pembiayaan perbankan. Untuk itu sudah semestinya usaha mikro kecil dilakukan pembinaan yang terencana sistemtatis dan tersturktur. Untuk memperoleh pembinaan ynang demikian harus melibatkan berbagai kajian dan analisis yang mendasarkan data yang akuntabel,

Secara konsep terdapat beberapa pengertian usaha mikro dan kecil. Menurut Undang-Undang No. 20 Tahun 2008 tentang UMKM memberikan pengertian dan klasifikasi berdasarkan aset dan omset tiap skala usaha [8]. Dikatakan usaha mikro jika kekayaan Bersih/Aset (tidak termasuk tanah dan bangunan tempat usaha) maksimal 50 juta rupiah dan hasil penjualan/omset maksmial 300 juta rupiah. Sedangkan yang dimaksud dengan usaha kecil jika usaha tersebut kekayaan Bersih/Aset (tidak termasuk tanah dan bangunan tempat usaha) lebih besar dari Rp50 juta sampai dengan Rp500 juta dan hasil penjulan/omset lebih besar Rp300 juta sampai dengan Rp2,5 Milyar

Berbeda dengan Undang-Undng no 20 tahun 2008 menurut Peraturan Gubeurnut nomor 30 tahun 2018 bahwa Usaha Mikro adalah usaha produktif milik orang perorangan dan/atau badan usaha perorangan yang memenuhi kriteria Usaha Mikro sebagaimana diatur dalam Undang-Undang Nomor 20 tahun 2008 tentang Usaha Mikro, Kecil dan Menengah dan/atau perubahannya. 
Sedangkan Usaha Kecil adalah usaha ekonomi produktif yang berdiri sendiri, yang dilakukan oleh orang perorangan atau badan usaha yang bukan merupakan anak perusahaan atau bukan cabang perusahaan yang dimiliki, dikuasai, atau menjadi bagian baik langsung maupun tidak langsung dan i usaha menengah atau usaha besar yang memenuhi kriteria usaha kecil sebagaimana diatur dalam Undang-Undang Nomor 20 tahun 2008 tentang Usaha Mikro, Kecil dan Menengah dan/atau perubahannya.

Peraturan Gubernur No 30 tahun 2018 tentang ........merupakan bukti bahwa pemerintah provinis DKI Jakarta memberikan pembinaan dari sisi legalitas usaha mikro kecil. Hal ini dimasukan bahwa dalam upaya memberikan dukungan nyata terhadap penciptaan iklim usaha yang kondusif sekaligus menyediakan lingkungan yang mampu mendorong pemberdayaan Usaha Mikro dan Kecil (UMK) secara sistematik, mandiri dan berkelanjutan melalui kebijakan dalam aspek perizinan usaha, maka perlu memberikan legalitas terhadap pelaku usaha mikro dan kecil;

Dengan adanya perizinan ini menunjukkan bahwa usaha mikro kecil memperoleh kepastian usaha dari sisi legal. Ini membuktikan bahwa aspek izin ini sangat staretegis agar usaha inin dapat melakukan tindakan hukum. Usaha mikro kecil ini mendapatkan kepastian dan perlindungan dalam berusaha. Selain itu, pemberian izin ini dimaksudkan agar usaha mikro kecil dapat mendapatkan pendampingan untuk pengembangan usaha, seperti : akses fasilitasi sertifikasi halal, PKP (Penyuluhan Keamanan Pangan), pameran dan bazaar. Hal yang pentng lagi adalah bahwa usaha ini juga untuk mendapat kemudahan dalam pemberdayaan.

Kegiatan usaha mikro kecil di Jakarta sangat variative. Beberapa aktivitas usahanya adalah, antara lain.

1. Toko/Warung (Kecuali toko obat, apotik, optik, toko obat hewan),

2. PKL (Berkeliling) : Tukang sayur/buah Perawatan, perbaikan, renovasi barang, laundry, penjahit

3. Kantor Jasa Perorangan (Arsitek, Programmer, dII).

4. Kedai Kopi/Warung Kopi, Pangkas Rambut \& Salon.

5. Agen Perjalanan Wisata., Warnet/Game Center (Tidak beroperasi 24 Jam)

6. Rumah Makan/Warung Makan/Warteg/Warsun.

7. Pencucian Kendaraan Roda dua, Bengkel Sepeda, tempat penitipan kendaraan

8. Katering Rumahan, agen koran dan pedagang pasar

9. Penjualan sarana perikaa,pertanian dan peternakan.

10. Studio Seni dan Keterampilan, Tempat kursus \& Pelatihan (Les privat dsb),).

11. Pengolahan Hasil Perikanan, Pertanian dan peternakan.

12. Tempat pengrajin kerajinan tangan, Bunga potong, rangkai bungan dan bibit tanaman, tanaman hias, tanaman produktif.

Dengan mendasarkan pada hal tersebut bahwa secara umum bahwa Usaha mikro kecil memounyai karekater yang spesifik. Tentu karakter ini berbeda dengan jenis usaha lainya. Menurut Bank Indonesia dan LPPI, bahwa karakteristik UMKM merupakan sifat atau kondisi faktual yang melekat pada aktifitas usaha maupun perilaku pengusaha yang bersangkutan dalam menjalankan bisnisnya. 
Karakteristik ini yang menjadi ciri pembeda antar pelaku usaha sesuai dengan skala usahanya. Menurut Bank Dunia, UMKM dapat dikelompokkan dalam tiga jenis, yaitu: 1. Usaha Mikro (jumlah karyawan 10 orang); 2. Usaha Kecil (jumlah karyawan 30 orang); dan 3. Usaha Menengah (jumlah karyawan hingga 300 orang).

Dalam perspektif usaha, UMKM diklasifikasikan dalam empat kelompok, yaitu:

Kelompok pertama : UMKM sektor informal, contohnya pedagang kaki lima.

Kelompok KEdua : UMKM Mikro adalah para UMKM dengan kemampuan sifat pengrajin namun kurang memiliki jiwa kewirausahaan untuk mengembangkan usahanya.

Kelompok KEtiga : Usaha Kecil Dinamis adalah kelompok UMKM yang mampu berwirausaha dengan menjalin kerjasama (menerima pekerjaan sub kontrak) dan ekspor.

Kelompok Keekmapt: Fast Moving Enterprise adalah UMKM yang mempunyai kewirausahaan yang cakap dan telah siap bertransformasi menjadi usaha besar.

Dengan melihat karakter dan jenis usaha mikro dan kecil maka dipelrukan pembinaan terpau yang koordinatif, dan focus terutama apda masa pandemic ini, pembinaan kepada usha mikro kecil perlu dikakukan secara lintas bidang dan lintas pealaku. Peningkatan kerjasama antara Kementerian/Lembaga, pemerintah daerah, institusi perbankan, fintech, marketplace dan seluruh pihak lain yang terlibat, untuk menyiapkan the Future SMEs agar UMKM dapat bersaing di pasar domestik dan pasar global (Kemenrtian Koperasi dan UKM, 2020 dalm KONTAN). Artinya kelompok usaha mikro dan kecil perlu mendapat perhatian agar dapat berperan dalam pembangunan ekonomi. Argumennya adalah bahwa perekonomian menurut Smith dalam Rahardja dan Mandala, bahwa perekonomian merupakan system maka perlu suati keseimbangan dan perekonomian mempunyai kemampuan untuk penstabilan otomatis untuk menjaga keseimbangannya [9]. Jadi dalam ekonomi akan mengarah ke titik keseimbangan.

Dalam hal digitalisasi ekonomi, pelaku usaha mikro kecil masih sangat minim. Padahal pada kenyataanya perubahan pola produksi distribusi dan konsumsi masyarkata suadah beruhbah dan membuthakan konsep bisnis digital. Oelha kern aitu, digitalisai bisnis pada ushaa mikro kecil mendajai suatau kebuththan yang mendesak. Berasaraka dasar dak kemerntiaterian kopersa dan ukm bahwa jumlah UMK yang sudah masuk ke ranah digital maish sedikit. Pembinaan difigtial bisnis kepada usaha mirko kecil dan menengan baru 8 juta UMKM hadir dalam platform digital. Besaran tersebut hanya 13\% dari total populasi UMKM. Namun demikian menurut Endang Puji, et al., Analisis Kota Jakarta sebagai Smart City dan Penggunaan Teknologi Infomrasi dan KOmuniaskai menuju Masyarakat Madani, bahwa di DKI Jakarta mulai bermunculan start up baru yang ditunjukkan dengan adanya perdagangan on-line.

\section{METODOLOGI PENELITIAN}

Dalam kaitanya dengan analisis maka digunakan pendekatan kualitatif, pendekatan yang digunakan adalah metode USG dan SWOT. Secara teori bahwa metode penelitian kualitatif adalah metode penelitian yang berlandaskan pada filsafat postpositivisme. Artinya bahwa pendekatan ini digunakan untuk meneliti pada kondisi 
obyek yang alamiah. Obyek yang diteliti didekati secara apa adanya tidak ada perlakuan khusus jadi benar benar natural. Oleh karena itu maka posisi peneliti menjadi instrument kunci. Kualitas hasil dari kajian ini sangat tergantung dari kualitas peneliti [11].

Dalam hal ini kajian dilakukan secara pendekatn kualitatif deskriptif. Pada kajian ini data diperoleh dari wawancara langsung dengan para pemangku kepentingan. Selain itu juga dilakukan secara purposive dengan pendekatan Forum Group Discussion (FGD). Kegiatan ini dimaksudakan agara data dapat diperoleh lebih berkualitas selain itu adalah bahwa iformasi tentang permasalahan akan bersifat lokal dan spesifik. Keunggulan dengan FGD yang kain adalah bahwa data akan sesuai dengan inti kajian.

Berbeda dengan data primer, data seconder dalam kajian ini dipeoleh dari dokumentasi yang pada instansi pemerintah yang bersesuaian. Jadi data diperoleh dari beberapa sumber yang akutantbilitasnya dapat dipertanggungjawabkan. Tahap selanjutnya adalah data seleksi dan dikelompokkan sesuai dengan tujuan analisis. Kualitas data dan informasi penting karena menurut Kaplan dalam Dunn, bahwa efektivitas penyusunan suatu kebijakan public tergantung dari ketersediaan dan aksesibilitas dari pengetahuan, data dan informasi yang berseusaian [12].

Tahap berikutnya adalah dilakkukan analisis dengan pendekatan USG (urgency seriousness growth). Untuk formulasi strategi digunakan pendekatan SWOT (Strength, weakness, Opportunity, dan Threats).

\section{Hasil Penelitian dan Pembahasan}

Tabel 1. Analisis USG

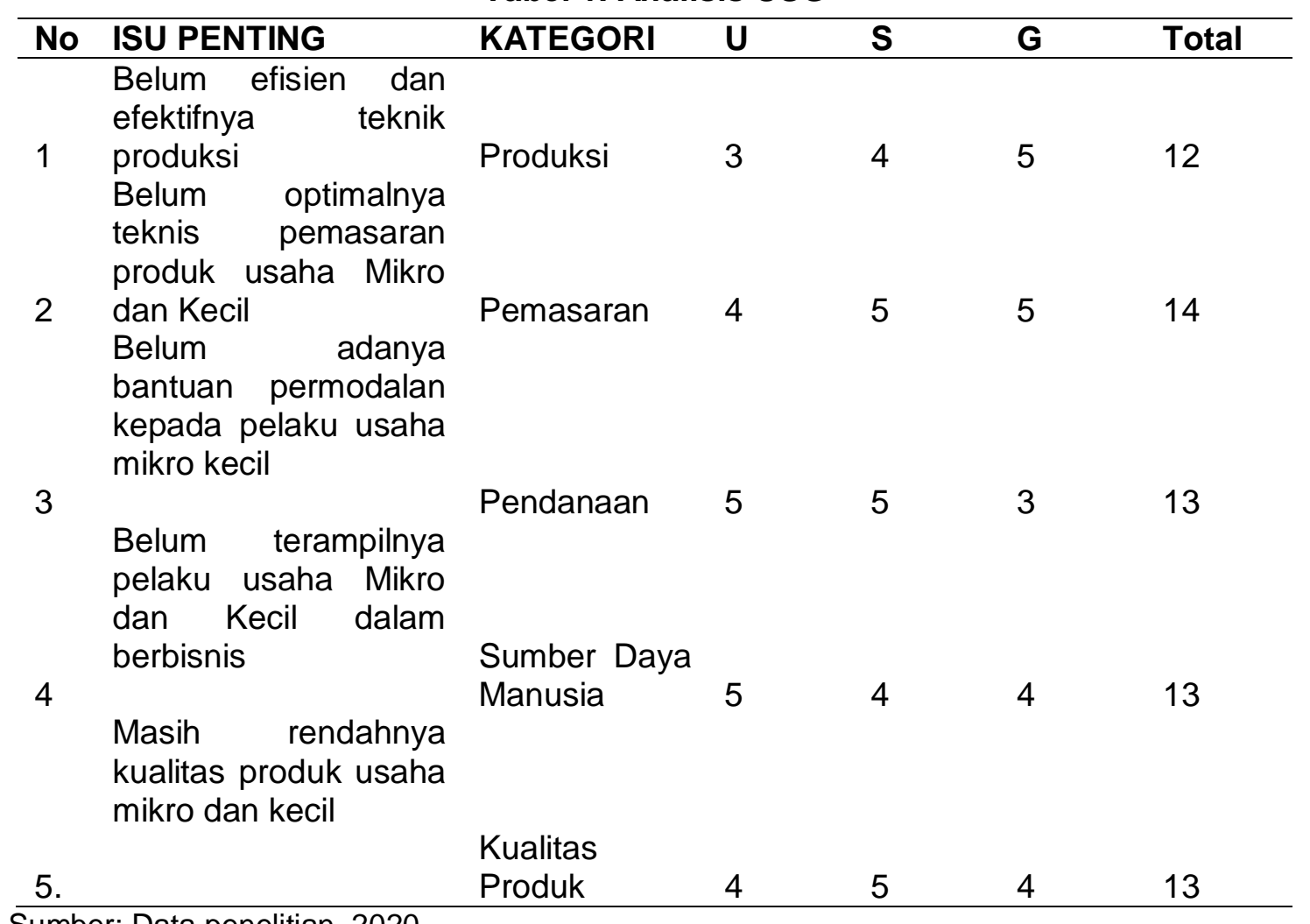

Sumber: Data penelitian, 2020 
Dengan mendasarkan pada perhitungan sebagaimana di atas diperoleh bahwa isu yang paling tinggi dari aspek urgency seriousness dan growth adalah isu : Belum optimalnya teknis pemasaran produk usaha Mikro dan Kecil, total skore nya adalah 14. Untuk itu, selanjutnya dianalisis dengan menggunakan analisis SWOT.

Tabel 2. Matrik Internal Factor Analysis Strategi (IFAS)

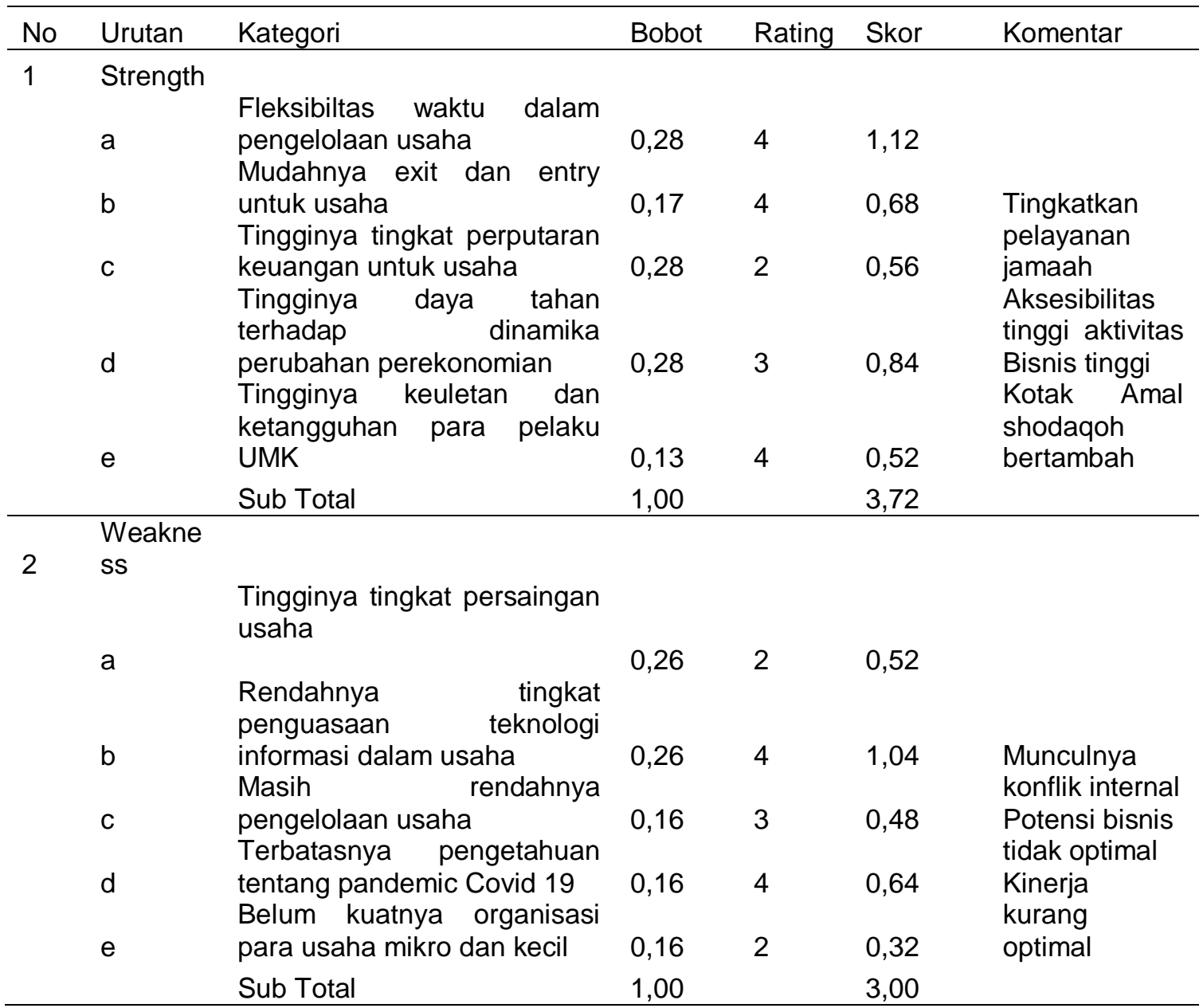

Sumber: Data penelitian, 2020

Sejalan dengan penyusunan Tabel IFAS, pada penyusunan table EFAS dilakukan dengan cara yang sama. Adapun Tabel EFAS adalah sebagai berikut.

Tabel 3. Tabel Matrik Eksternal Factor Analysis Strategi (EFAS)

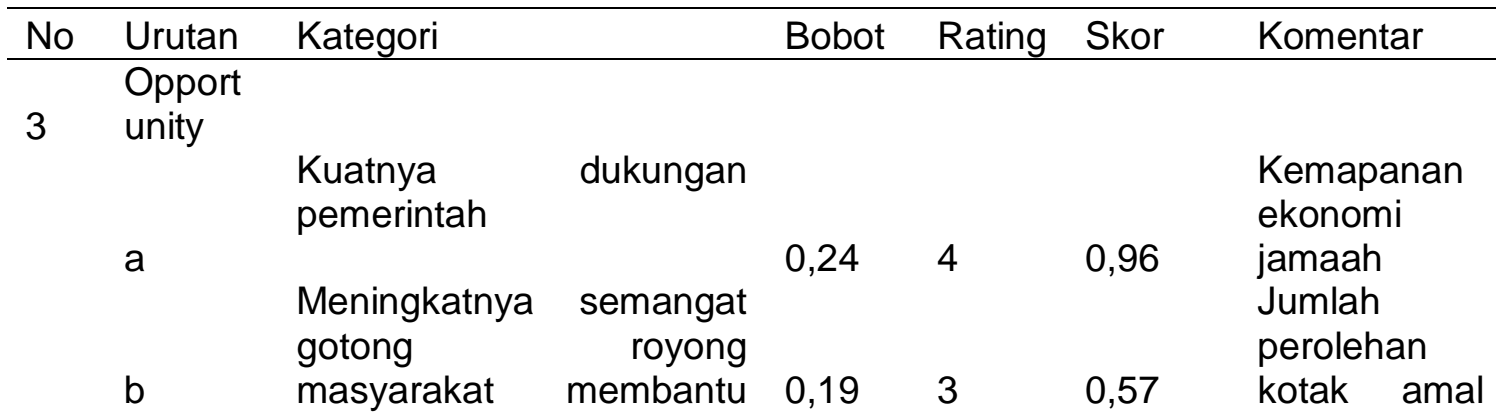




\begin{tabular}{|c|c|c|c|c|c|c|}
\hline No & Urutan & Kategori & Bobot & Rating & Skor & Komentar \\
\hline & & UMK & & & & bertambah \\
\hline & & Kuatnya & & & & Intensitas \\
\hline & & kebersamaan & & & & kehadiran \\
\hline & C & Usaha Mikro & 0,14 & 2 & 0,28 & pejabat \\
\hline & & $\begin{array}{l}\text { Besarnya potensi pasar } \\
\text { untuk Produk Usaha Mikro }\end{array}$ & & & & $\begin{array}{l}\text { Luas lahan } \\
\text { mencukupi }\end{array}$ \\
\hline & d & kecil & 0,24 & 4 & 0,96 & \\
\hline & & Lengkapnya infrastruktur & & & & \\
\hline & e & perekonomian Jakarta & 0,19 & 2 & 0,38 & \\
\hline & & Sub Total & 1,00 & & 3,15 & \\
\hline 4 & $\begin{array}{l}\text { Threate } \\
\text { ns }\end{array}$ & & & & & \\
\hline & & $\begin{array}{lr}\text { Tingginya } & \text { tingkat } \\
\text { penyebaran } & \text { Pandemic }\end{array}$ & & & & \\
\hline & a & $\begin{array}{l}\text { Covid } 19 \\
\text { Merebaknya digitalisasi } \\
\text { pemasaran produk usaha }\end{array}$ & 0,22 & 4 & 0,88 & \\
\hline & $b$ & mikro kecil & 0,22 & 4 & 0,88 & \\
\hline & & $\begin{array}{l}\text { Lemahnya daya beli } \\
\text { masyarakat sebagai } \\
\text { dampak Pandemic Covid }\end{array}$ & & & & \\
\hline & C & $\begin{array}{l}19 \\
\text { Bertambahnya jumlah }\end{array}$ & 0,22 & 4 & 0,88 & $\begin{array}{l}\text { Peningkatan } \\
\text { daya }\end{array}$ \\
\hline & d & $\begin{array}{l}\text { pekerja yang di PHK } \\
\text { Tingginya } \\
\text { ketidaknyamanan } \\
\text { masyarakat terhadap }\end{array}$ & 0,22 & 4 & 0,88 & $\begin{array}{l}\text { Kompetisi } \\
\text { Mitigasi } \\
\text { resiko } \\
\text { Laporan }\end{array}$ \\
\hline & e & $\begin{array}{l}\text { kuliatas produk usaha } \\
\text { mikro kecil. }\end{array}$ & 0,12 & 3 & 0,36 & $\begin{array}{l}\text { bisnis kurang } \\
\text { tertata }\end{array}$ \\
\hline & & Sub Total & 1,00 & & 3,88 & \\
\hline
\end{tabular}

Sumber: Data penelitian, 2020

Selanjutnya untuk memudahkan penyusunan grand strategy pengembangan ekonomi masjid dilakukan penyusunan matrik penggabungan antara IFAS dan EFAS. Aktivitas ini dilakukan untuk memudahkan dalam penggambaran diagram kartesius SWOT. Secara rinci matriks Penggabungan IFAS dan EFAS adalah sebagai berikut.

Tabel 4. Matriks Penggabungan IFAS + EFAS

\begin{tabular}{lllll}
\hline Sub Total Strength & $=3,72$ & Sub Total Weakness & $=3,00$ & 0,72 \\
Sub Total Opportunity & $=3,15$ & Sub Total Threatens & $=3,88$ & Minus 0,73 \\
Sub Total S + O & $=6,87$ & Sub Total W $+\mathrm{T}$ & $=6,88$ & \\
\hline
\end{tabular}

Sumber: Data penelitian, 2020

Untuk menentukan strategy pembinaan usaha mikro kecil pada masa pandemic Covid 19 digunakan hasil penggabungan nilai IFAS dan EFAS. Dengan dasar ini dibuat diagram kartesius. Secara terinci diagram karetsius pembinaan. 


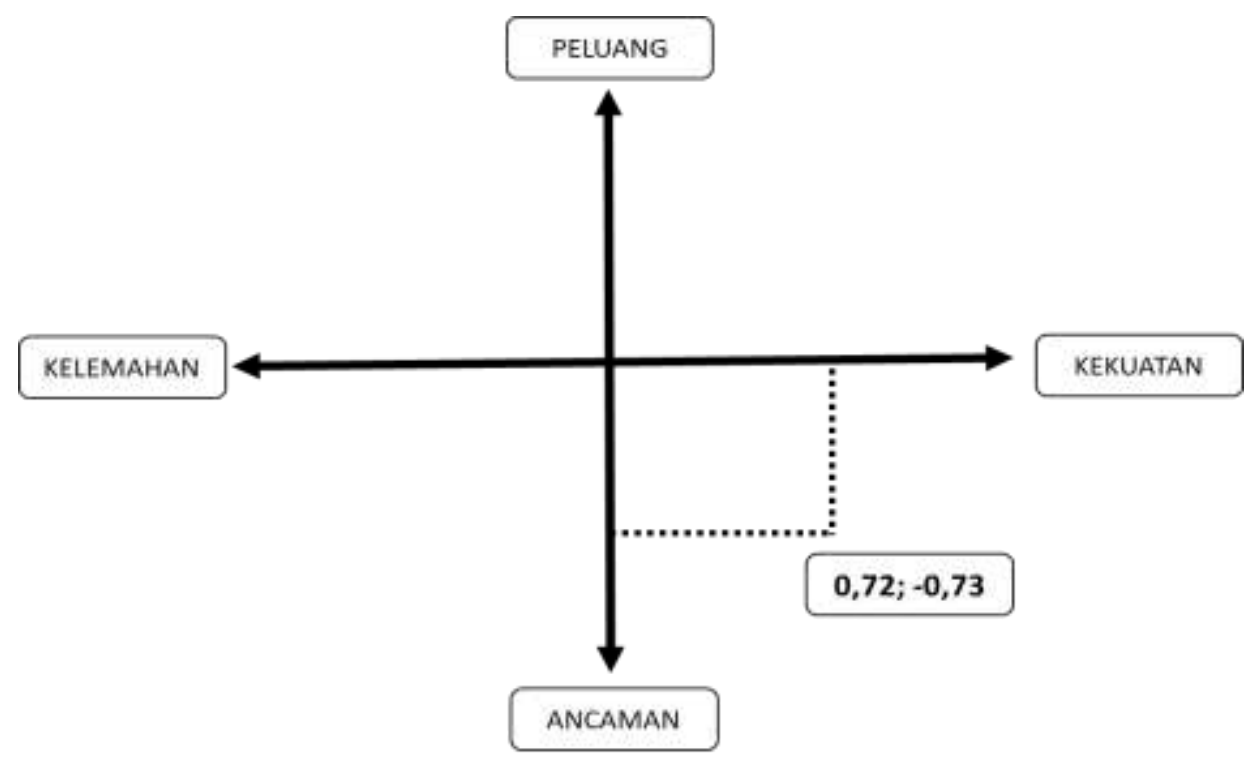

\section{Diagram 1. Diagram Kartesius Pemberdayaan Usaha Mikro Kecil Masa Pandemic} Covid 19 di Jakarta

Berdasarkan perhtungan ditemukan bahwa nilai total IFAS adalah 0,72 dan nilai total EFAS adalah - 0,73. Dengan demikian pengembangan usha mikro kecil di masa pencemic Covid 19 di Jakarta berada pada Kuadran II. Menurut, bahwa posisi kuadran II adalah posisi dengan karakter mendukung strategi diversifikasi [13]. Hal ini ditandai bahwa meskipun menghadapi berbagai ancaman, organisasi masih memiliki kekuatan dari segi internal. Strategi yang harus diterapkan adalah menggunakan kekuatan untuk memanfaatkan peluang jangka panjang dengan cara strategi diversifikasi (produk/jasa).

Berdasarkan diagram kartesius diperoleh strategy dalam pengembangan usaha mikro kecil pada masa pandemic Covid 19 disusun strateginya. Berkatian dengan hal ini maka berikut disusun matirk SWOT untuk menyusun strategy pembinaan usaha mikro kecil tersebut agar lebih operasional. Berikut matriks SWOT nya, sebagai berikut.

Selanjtunya untuk memudahkan dalam penyusunan strategi maka disusun matriks SWOT. Dengan dasar ini maka akan diperoleh suatu strategi yang tepat dalam pengembangan usaha mikro dan kecil.

Tabel 5 . Matriks SWOT Pemberdayaan Pemberdayaan Usaha Mikro Kecil Masa Pandemic Covid 19 di Jakarta

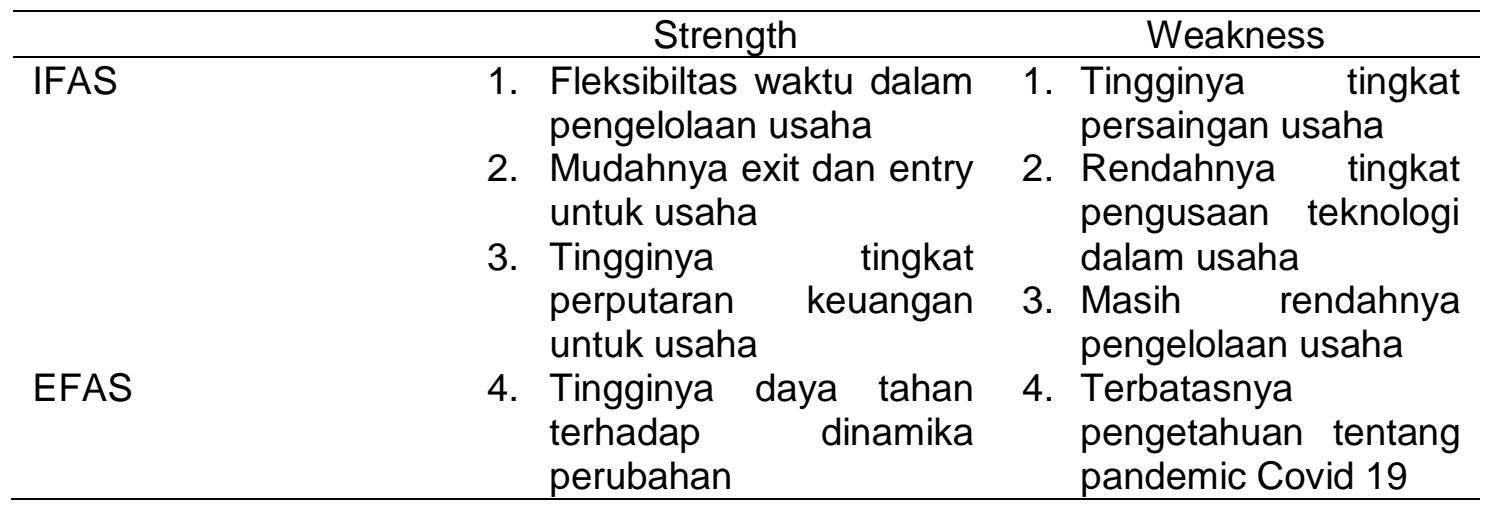




\begin{tabular}{|c|c|c|}
\hline & $\begin{array}{l}\text { perekonomian } \\
\text { 5. } \begin{array}{l}\text { Tingginya keuletan dan } \\
\text { ketangguhan para } \\
\text { pelaku UMK }\end{array}\end{array}$ & $\begin{array}{l}\text { 5. Belum kuatnya } \\
\text { organisasi para usaha } \\
\text { mikro dan kecil }\end{array}$ \\
\hline $\begin{array}{l}\text { Opportunity } \\
\text { 1. Kuatnya dukungan } \\
\text { pemerintah } \\
\text { 2. Meningkatnya } \\
\text { semangat gotong } \\
\text { royong masyarakat } \\
\text { membantu UMK } \\
\text { 3. Kuatnya rasa } \\
\text { kebersamaan } \\
\text { pelaku Usaha } \\
\text { Mikro potensi } \\
\text { 4. Besarnya } \\
\text { pasar untuk Produk } \\
\text { Usaha Mikro kecil } \\
\text { 5. Lengkapnya } \\
\text { infrastruktur } \\
\text { perekonomian } \\
\text { Jakarta }\end{array}$ & $\begin{array}{l}\text { Strategi S-O } \\
\text { 1. Peningkatan pelatihan } \\
\text { SDM dalam hal } \\
\text { digitalisasi usaha } \\
\text { dengan dengan bantuan } \\
\text { pemeirntah } \\
\text { 2. Pendampingan usaha } \\
\text { dengan } \\
\text { pemeritnah bantuan } \\
\text { 3. Kapitalisasi modal dari } \\
\text { berbagai sumber } \\
\text { 4. Ekspansi bisnis yang } \\
\text { sudah berjalan }\end{array}$ & $\begin{array}{l}\text { Strategi W-O } \\
\text { 1. Pemanfaatan } \\
\text { dukungan fasilitas } \\
\text { dari pemerintah } \\
\text { secara optimal } \\
\text { 2. Permohonan CSR } \\
\text { kepada dunia usaha } \\
\text { besar }\end{array}$ \\
\hline $\begin{array}{l}\text { Threats } \\
\text { 1. Tingginya tingkat } \\
\text { penyebaran } \\
\text { Pandemic Covid } 19 \\
\text { 2. Merebaknya } \\
\text { digitalisasi } \\
\text { pemasaran produk } \\
\text { usaha mikro kecil } \\
\text { 3. Lemahnya daya } \\
\text { beli masyarakat } \\
\text { sebagai dampak } \\
\text { Pandemic Covid } 19 \\
\text { 4. Bertambahnya } \\
\text { jumlah pekerja } \\
\text { yang di PHK } \\
\text { 5. Tingginya } \\
\text { ketidaknyamanan } \\
\text { masyarakat } \\
\text { terhadap kuliatas } \\
\text { produk usaha } \\
\text { mikro kecil. }\end{array}$ & 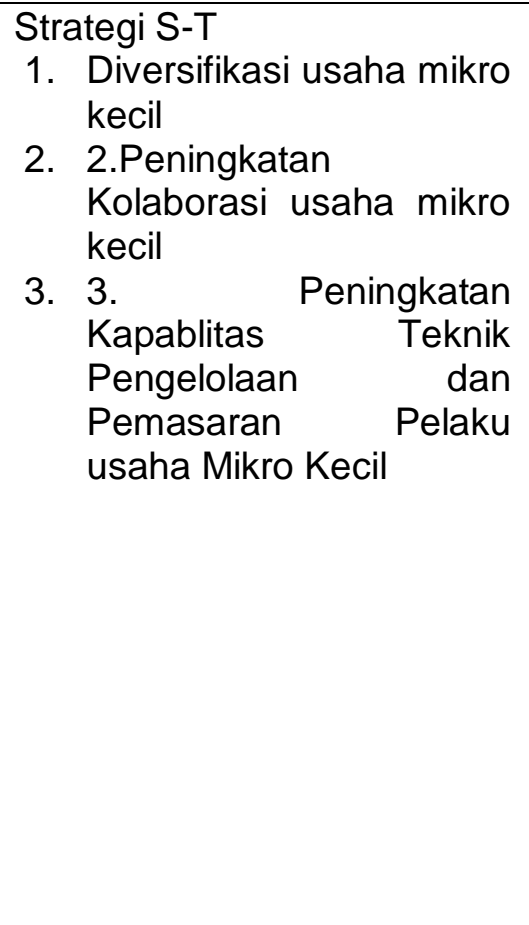 & $\begin{array}{l}\text { Strategi W-T } \\
\text { 1. Menjajagi para } \\
\text { pengusaha besar } \\
\text { yang memberikan } \\
\text { dana tanpa ikatan } \\
\text { 2. Mendekati ahli bisnis } \\
\text { yang gratis } \\
\text { 3. } 3 . \quad \text { Pemohonan } \\
\text { bantuan fasilitas } \\
\text { kepada pemerintah }\end{array}$ \\
\hline
\end{tabular}

Sumber: Data penelitian, 2020

\section{KESIMPULAN DAN SARAN}

Dari kajian dan hasil analisis tentang usaha pembinaan usaha mikro dan kecil di masa pandemic Covid 19 dilakukan dengan pendekatan analisis USG, SWOT, EFAS dan IFAS. Dari hasil dikusi dan analisisi diperoleh beberapa kesimpulan yang aggregative sebagai berikut. 
1. Usaha Mikro kecil mempunyai karakter yang khusus, yaitu antara lain adalah perputaran usaha (turn over) cukup tinggi, tidak sensitive terhadap suku bunga, tetap berkembang walau dalam situasi krisis ekonomi dan moneter, Pada umumnya berkarakter jujur, ulet, lugu dan dapat menerima bimbingan asal. Selain itu, varian usahanya yang luas.

2. Usaha mikro kecil DKI Jakarta terdampak juga oleh pandemic Covid 19. Omset menurutn, pendaptan menurun dan pada akhirnya keuntungan juga menurun cukup signifikan. Sejalan dengan hal ini maka diperlukan usaha yang kompterhensif, dan integraif dan koordiniatdif serta kolaborataif agar usaha mikro kecil ini tetap dapat berusaha dan tetap eksis dan mampu berkontribusi dalam perekonomian Jakarta.

3. Pelaku usaha mikro kecil mempunyai peran yang penting dalam menunjang dan berkontribusi pada perekonomian Jakarta. Dengan demikian jika kelompok usaha ini tidak berjalan dengan regular maka akibat yang ditimbulkan cukup serius. Akibatnya dapat mengarah kepada kelesuan ekonomi juga mengarah ke stabilitas sosial.

4. Berdasarkan hasil analisis dengan menggunakan metode USG, dari lima isu penting yang telah diperoleh dari FGD ditemukan isu yang mendesak, serius dan perlu segera dicarikan jalan solusinya secara cepat. Isu tersebut adalah "Belum optimalnya teknis pemasaran produk usaha Mikro dan Kecil"

5. Berdasarkan perhtungan ditemukan bahwa nilai total IFAS adalah 0,72 dan nilai total EFAS adalah - 0,73. Dengan demikian pengembangan usha mikro kecil di masa pencemic Covid 19 di Jakarta berada pada Kuadran II. Mendasarkan pada analisis maka strategi yang harus diterapkan dalam pembinaan usaha mikro kecil pada masa Pandemic Covid 19 adalah menggunakan kekuatan untuk memanfaatkan peluang jangka panjang dengan cara strategi diversifikasi (produk/jasa).

6. Berdasarakan kajian ini teridentifikasi tiga strategi dalam pembinaan usaha mikro kecil pada masa Pandemic Covid 19. Ketiga strategi tersebut adalah :

a. Diversifikasi usaha mikro kecil

b. Peningkatan Kolaborasi usaha mikro kecil

c. Peningkatan Kapablitas Teknik Pengelolaan dan Pemasaran Pelaku usaha Mikro Kecil

Selanjutnya berdasarkan ketiga strategi ini disusun program yang komperhensif. Dari program ini perlu disusun kegiatan yang tepat sesuai dengan kebutuhan. Jika demikian maka akan memudahkan dalam penyusunan indikator keberhasilan dan penyusunan evaluasi .

Dengan memperhatikan hasil dari pembahasan dan kesimpulan maka disarankan bahwa untuk pembinaan usaha mikro kecil pada masa pendemic Covid 19 di lingkungan DKI Jakarta disarnakan beeberapa hal, yaitu :

1. Perlu dilakukan kolaborasi antara usaha mikro kecil dengan pemangku kepentingan lainnya. Kolaborasi ini meliputi pemeirntah dunia usaha, menengah dan besar serta akdemisi. Hal ini dmakusdkan ada konsep yang jelas dan implementable unutk pembinaan usaha mikro keicl DKI Jakarta pada mas pncmeic 
COvid 19. Tentunya dilakukan secara proporsioanl dan proefional agara terwujud usaha mikrao yhang resilience dan sustainable. Hal sejalan dengan temuan Yurianto ( 2020) bahwa kerja sama Pemreintah Provinsi DKI Jakarta, BUMD, BUMN dan BUMD Pemerintah lainnya cukup efektif dalam suatu program di sekotr public.

2. Perlu dilakukan clusterifikasi antara pelaku usaha mirko kecil yang tepat. Cluster usaha mikro keicl yang sudah eksis terdahulu dengan usaha mikro kecil yang muncu akiabta pancmeid covid 19. Cluster usaha mikro kecil ini perlu dibina dengan baik dan sudah tentu dalam hal ini pelur dilakuan dengan pendekatan yang bspesifik dan tidka bisa disamakan. Hal ini dimaksudkan agar menghasilkkan outcome yang optimal.Dalam pembinaan ini harus dengan tujuan yang jelas, lugas, dan tegas aar memudahkan dalam evaluasi (Kepner dan Tragoe 1992).

3. Mengingat vaksin codona masih belum ditmeukana maka akiabta wabha ini terhadpa usaha mikro kecil masih bekum terpreidki kapan akan selesai. Sehalan dengan ii naka dipelrukan prencanaan pembinaan yang lebih lkomprhenisd dan menyeluruh. Dalam hal ini pemebriran dana dan anggaran kepada para pelakua usaha mikro kecil perlu dilakukan dengan adil dan merata. System pemberian dana harus disusun secara komprehensif dengan melibatkan berbagai pihak. Namun harus segera dilakkan. Sambail berjalan sistgema tersu diperbaikaik

4. Perlu pengembangan sumber daya manusia para perilaku usaha mirko kecil lingkup yagn mendesak peru dilakukan adalah dengan pembinaan dalam kontek teknis pemasaran menjadi sangat penting. Selain itu perlu disusun stretgu unutk pendampingan yang friendly terhadap para pelaku usaha nirko kecil.

5. Perlu dilakukan usaha yang terencana dan cepat dalam usaha membantu upaya pemasaran produk koperasi dan UKM dengan menyertakan UMKM dalam platform belanja pemerintah serta platform belanja BUMN.

\section{DAFTAR PUSTAKA}

[1] Sugiri, D. (2020). Menyelamatkan usaha mikro, kecil dan menengah dari dampak pandemi Covid-19. Fokus Bisnis: Media Pengkajian Manajemen dan Akuntansi, 19(1), 76-86.

[2] Wahyudi, M., Mukrodi, M., Harras, H., \& Sugiarti, E. (2020). Wirausaha Muda Mandiri: Learning, Sharing \& Practice. SCIENTIFIC JOURNAL OF REFLECTION: Economic, Accounting, Management and Business, 3(1), 101110.

[3] Saprianto, F. (2020). DILEMATIS UMKM DI ERA DIGITAL. SCIENTIFIC JOURNAL OF REFLECTION : Economic, Accounting, Management and Business, 3(1), 21-30

[4] Baker, T., \& Judge, K. (2020). How to Help Small Businesses Survive COVID-19. Columbia Law and Economics Working Paper, (620).

[5] Saragih, R., \& Elisabeth, D. M. (2020). Kewirausahaan Sosial Dibalik Pandemi Covid-19: Penelusuran Profil dan Strategi Bertahan. Jurnal Manajemen, 1(1), 4756. 
[6] Murdani, M., \& Hadromi, H. (2019). Pengembangan Ekonomi Masyarakat Melalui Pemberdayaan Usaha Mikro Kecil dan Menengah (Studi di Kelurahan Kandri Kecamatan Gunungpati Kota Semarang). Jurnal Abdimas, 23(2), 152-157.

[7] Bank Indonesia dan LPPI, 2015. Profil Bisnis Usaha Mikro, Kecil dan Menengah (UMKM). Jakarta

[8] Undang-Undang No. 20 Tahun 2008 tentang Usaha Mikro Kecil dan Menengah

[9] Sari, S. P. (2020). STRATEGI MENINGKATKAN PENJUALAN DI ERA DIGITAL. SCIENTIFIC JOURNAL OF REFLECTION: Economic, Accounting, Management and Business, 3(3), 291-300.

[10] Astutik, E. P., \& Gunartin, G. (2019). ANALISIS KOTA JAKARTA SEBAGAI SMART CITY DAN PENGGUNAAN TEKNOLOGI INFORMASI DAN KOMUNIKASI MENUJU MASYARAKAT MADANI. INOVASI, 6(2), 41-58.

[11] Sugiyono. (2018). Metode Penelitian Kuantitatifm dan Kualitatif dan R \& D. Alfabeta. Bandung.

[12] Dunn, W. N. (2003). Pengantar Analisis Kebijakan Publik Edisi Kedua. Yogyakarta: Gajah Mada University.

[13] Marimin (2004). Teknik dan Aplikasi Pengambilam Keputusan Kriteria Majemuk, Grasindo, Penerbit PT. Gramedia Widiasarana Indonesia, Jakarta. 